\title{
PENDEKATAN KONSELING BEHAVIORAL TERHADAP PERKEMBANGAN MORAL SISWA
}

\author{
Bestari Laia', Murnihati Sarumaha $^{2}$, Merri Christina Zalukhu ${ }^{3}$, \\ Mastawati Nduru ${ }^{4}$, Tatema Telaumbanua ${ }^{5}$, Lies Dian Marsa Ndraha ${ }^{6}$, \\ Darmawan Harefa ${ }^{7}$. \\ 1,2,3,4,5,6,7. STKIP Nias Selatan, Indonesia.
}

\begin{abstract}
Email: laiabestari211087@ gmail.com ${ }^{1}$, murnisarumaha2016@ gmail.com² merrichristinaz@gmail.com ${ }^{3}$, mastawatindruru@gmail.com ${ }^{4}$, tatematelaumbanua72@gmail.com $^{5}$, liyesu.ndraha@gmail.com ${ }^{6}$, darmawan90_h24@yahoo.co.id7.
\end{abstract}

\begin{abstract}
The purpose of this study was to describe the level moral development of students before and after being treated, as well as to examine the behavioral counseling approach the moral development of students of SMP Negeri 1 Aramo. This research uses quantitative research with experimental research methods. The population in this study were all students of SMP Negeri 1 Aramo, totaling 200 students, and a sample of 25 students using purposive sampling technique. The data analysis technique in this study used simple linear regression analysis. Based on the results of the study, it was found that the level of moral development was in the high category with a percentage of $75.20 \%$ and an average score of students 88.94,3) the coefficient of determination with value. Regression model which means rejected and accepted. It can be concluded there is a behavioral counseling approach to students' moral development.
\end{abstract}

Keywords: Approach, Counseling, Moral Development.

\begin{abstract}
ABSTRAK
Tujuan penelitian ini adalah untuk mendeskripsikan tingkat perkembangan moral siswa sebelum dan sesudah diberikan perlakuan, serta untuk mengetahui pendekatan konseling perilaku terhadap perkembangan moral siswa SMP Negeri 1 Aramo. Penelitian ini menggunakan penelitian kuantitatif dengan metode penelitian eksperimental. Populasi dalam penelitian ini adalah seluruh siswa SMP Negeri 1 Aramo yang berjumlah 200 siswa, dan sampel sebanyak 25 siswa dengan menggunakan teknik purposive sampling. Teknik analisis data dalam penelitian ini menggunakan analisis regresi linier sederhana. Berdasarkan hasil penelitian diketahui bahwa tingkat perkembangan moral berada pada kategori tinggi dengan persentase $75,20 \%$ dan nilai rata-rata siswa 88,94, 3) koefisien determinasi dengan nilai. Model regresi yang artinya ditolak dan diterima. Sehingga dapat disimpulkan ada pendekatan konseling perilaku terhadap perkembangan moral siswa.
\end{abstract}

Kata Kunci: Pendekatan, Konseling, Pengembangan Moral.

\section{PENDAHULUAN}

Perkembangan ilmu pengetahuan dapan meningkatkan berbagai ilmu pengetahuan yang dimiliki oleh peserta didik. Salah satu cara meningkatkan mutu pendidikan di sekolah adalah pemberian layanan bimbingan konseling. Bimbingan konseling di sekolah merupakan bantuan yang diberikan kepada siswa dalam upaya menemukan pribadi, mengenal lingkungan dan merencanakan masa depan. Secara umum makna pendidikan merupakan sarana mutlak yang dipergunakan untuk mewujudkan masyarakat menjadi mampu menguasai, mengembangkan, mengendalikan dan memanfaatkan ilmu pengetahuan dan teknologi. Melalui pendidikan, siswa dipersiapkan menjadi masyarakat cerdas dan berguna bagi nusa dan bangsa. Mengingat pentingnya pendidikan maka telah banyak usaha yang dilakukan pemerintah untuk meningkatkan mutu pendidikan di Indonesia. Dalam Pasal 1 Undang-Undang Nomor 20 Tahun 2003 tentang sistem pendidikan nasional menyatakan bahwa pendidikan merupakan usaha 
sadar dan terencana untuk mewujudkan suasana belajar dan proses pembelajaran agar peserta didik secara aktif mengembangkan potensi dirinya untuk memiliki kekuatan spiritual keagamaan, pengendalian diri, kepribadian, kecerdasan akhlak mulia, serta keterampilan yang diperlukan dirinya, masyarakat, bangsa, dan negara.

Konseling behavioral menganalisis perilaku tampak yang dapat diukur, dilukiskan dan diramalkan. Terapi perilaku ini lebih mengkonsentrasikan pada modifikasi tindakan, dan berfokus pada perilaku saat ini daripada masa lampau.Willis (2010:70) mengemukakan bila konselor memandang kelainan perilaku sebagai kebiasaan yang dipelajari. Karena itu dengan situasi positif yang direkayasa kelainan perilaku negative dapat berubah menjadi positif. Dalam konsep behavioral, perilaku merupakan hasil belajar, sehinga dapat diubah dengan manipulasi dan mengkreasi kondisi-kondisi belajar. Pada dasarnya, proses konseling merupakan suatu penataan proses atau pengalaman belajar untuk membantu individu mengubah perilakunya agar dapat memecahkan masalah. Belajar merupakan proses perubahan perilaku yang disebabkan oleh pengalaman. perubahan Anak yang merasa enggan melakukan pelanggaran aturan merupakan hasil dari belajar anak yang telah belajar mengetahui akibat dari perbuatan melanggar karena dapat merugikan diri dan orang lain. Reaksi ini dapat diperoleh secara tidak sadar maupun secara sadar dan juga dapat diperoleh dari hasil belajar.

Berdasarkan berbagai pengertian yang telah dikemukakan diatas, dapat simpulkan bila pendekatan konseling behavioral adalah teknik pendekatan dalam konseling yang diberikan kepada siswa agar mampu belajar merubah tingkah laku bermasalah menjadi sesuai dengan norma dan aturan yang berlaku. Individu yang baru berkembang mulai menyadari bila setiap orang harus menyesuaikan diri agar bisa diterima dalam kelompok sosial (Laia, 2018). Melihat ini peneliti mengetahui bila masa SMP merupakan masa transisi dalam perkembangan fisik dan moral, saat seseorang mulai beralih dari remaja menuju dewasa, saat seseorang dalam perkembangan fisik dan psikis yang butuh perhatian yang lebih untuk diakui keberadaanya, meski masih banyak yang salah memahami dan mengerti tentang cara berperilaku, apakah itu perilaku yang bermanfaat atau tidak sehingga individu dalam masa remaja menuju dewasa ini mengalami kesulitan-kesulitan untuk menyesuaikan diri dengan lingkungannya dan tentu menghambat perkembangan moral (Harefa, 2017). Dari kesulitan-kesulitan itu maka dengan bantuan konseling behavioral peneliti mencoba merubah perilaku menyimpang menjadi perilaku yang mengikuti norma seperti datang kesekolah tepat waktu, tidak membolos, menghormati guru, menghargai teman dan perilaku menyimpang lain yang terjadi disekolah (Laia, 2019). Perilaku siswa yang bermasalah seperti tidak menghargai guru, kurang disiplin, berperilaku kasar, dan melakukan tindakan fandalis dapat dieleminasi melalui pendekatan behavioral dengan bantuan guru bimbingan dan konseling untuk meningkatkan kualitas kepribadian siswa, memberi harapan besar pada mereka yang saat ini terlihat bermasalah dengan perilakunya agar mempunyai kesempatan yang sama dengan siswa yang lain untuk menjadi orang yang berguna dimasa depan (Laia, 2019).

Berdasarkan pengamatan yang diperoleh Peneliti dengan melakukan observasi langsung di SMP Negeri 1 Aramo dengan melihat catatan piket harian selama semester ganjil dari bulan januari sampai bulan Juni tahun 2020 terdapat data siswa-siswa yang mengabaikan aturan sekolah seperti kurang menghormati guru, berperilaku kasar, bolos/cabut les, datang terlambat dan perilaku fandalis seperti merusak fasilitas sekolah. Penulis melihat semua masalah itu berkaitan dengan bagaimana siswa masih belum memiliki kesadaran moral yang berkembang maka layanan bimbingan dan konseling perlu diberikan, dalam penelitian ini penulis menggunakan konseling behavioral untuk membantu siswa menghadapi masalah siswa. Berikut tabel daftar buku kasus siswa dibawah ini dari catatan semester Sumber: Buku Kasus 
siswa sekolah SMA Negeri 1 Mazinö semester Ganjil,dari bulan Januari sampai bulan Juni tahun 2019:

Tabel 1.1 Daftar Kasus Siswa SMP Negeri 1 Aramo Tahun Pelajaran 2019/2020 No Jenis Perilaku Bermasalah Jumlah Kasus

\begin{tabular}{cll}
\hline $\mathbf{1 .}$ & Terlambat datang kesekolah & 54 kasus/ orang \\
\hline $\mathbf{2 .}$ & Bolos/cabut les & 37 kasus/orang \\
\hline 3. & MembuatKeributan & 62 kasus/orang \\
\hline 4. & Berkelahi/ tawuran & 42 kasus/orang \\
\hline $\mathbf{5 .}$ & Tidak mengerjakan tugas/Pr & 47 kasus/orang \\
\hline & Jumlah keseluruhan & 242 kasus/ orang \\
\hline
\end{tabular}

Jumlah kasus dari daftar ini mewakili jumlah siswa yang berkasus tapi beberapa siswa tercatat dengan jenis perilaku bermasalah yang berbeda, maksudnya ialah terdapat siswa dengan catatan perilaku bermasalah dengan dua, tiga bahkan lebih jenis perilaku bermasalah yang telah dilakukan. Catatan itu dibuat sabagai jamin agar siswa dapat merubah perilaku selain hukuman pendisiplinan yang diberikan seperti dengan disuruh berdiri depan kelas, menghormati bendera dan hukuman fisik lainnya. Jika pelanggaran termaksud pelanggaran berat maka siswa akan diberi surat panggilan orangtua dan bila dianggap tidak bisa berubah maka sekolah akan mengembalikan siswa kepada orang tua atau diberi surat pindah kesekolah lain. Dari hasil wawancara dengan dengan guru yang menangani bidang kesiswaan tercatat ada 7 orang siswa yang telah dipecat selama semesterganjil dari bulan 1 Januari sampai bulan juni tahun pelajaran 2019 dengan kasus Melawan guru, sering bolos sekolah dan karena masalah perkelahian.

Tanpa melihat faktor kondisi lingkungan tentu pihak sekolah tidak akan melihat secara mendalam penyebab dari perlaku bermasalah yang sering dilakukan oleh siswa, dari hasil observasi dan wawancara penulis mencatat beberapa alas an seperti kenapa siswa banyak yang terlambat, alasannya seperti jika cuaca hujan maka siswa akan kesulitan datang tepat waktu karena jarak lokasi sekolah dari rumah yang berjauhan, dan satu desa yakni desa lawindra yang siswanya harus melewati sungai untuk kesekolah apalagi jika sungai banjir sudah tentu siswa akan datang terlambat dan bahkan tidak datang lagi kesekolah jika banjir tidak kujung surut.

Penyebab perkelahian yang disebabkan oleh kesalah pahaman dengan teman, dan bahkan hal sepele seperti tidak terima kelakar karena merasa direndahkan. Siswa yang melawan guru berdalih bila guru semena-mena dalam memberi aturan dan hukuman (Harefa, D., Sarumaha, 2020). Keributan didalam kelas biasanya terjadi karena kelas ditinggalkan oleh guru mata pelajaran, untuk tugas atau PR yang tidak dilaksanakan dikarenakan siswa harus mengerjakan tugas yang diberi orang tua seperti harus keladang atau kebun, mengurus ternak, dan pekerjaan rumah yang dirasa siswa menjadi sulit dalam membagi waktu untuk belajar dan mengerjakan PR yang diberikan (Sarumaha, M., 2018). Dari semua alasan dan penyebab yang ditemukan dari hasil observasi dan wawancara tentu ada yang benar dan juga tidak, karena beberapa siswa memang tidak sepenuhnya dalam kondisi lingkungan desa dan keluarga yang sama.

Dalam proses observasi dan wawancara yang dilakukan peneliti dapat di ketahui beberapa guru memberi hukuman karena melihat siswa bermasalah sebagai ancaman yang menggangu ketertiban sekolah SMP Negeri 1 Aramo dan mengangap mereka yang bermasalah tidak dapat diubah menjadi siswa dengan pribadi yang baik, sehingga peneliti ingin mengangkat hal ini sebagai bahan penelitian dan memberi bantuan kepada siswa yang sedang dalam perkembangan moral untuk dapat menjadi pribadi yang baik melalui konseling behavioral, penulis berharap dengan pelaksanaan konseling 
behavioral siswa mampu mengembangkan moral mereka kearah yang lebih baik dan menjadi orang yang berguna untuk saat ini dan di masa yang akan datang .

Berdasarkan identifikasi masalah dari observasi langsung dan dengan melihat buku catatan piket harian, peneliti melihat masalah-masalah siswa di SMA Negeri 1 Mazinö berkenaan dengan masalah perkembangan moral, hal ini hendak diteliti secara ilmiah, maka peneliti merumuskan judul penelitian ini tentang "Pendekatan Konseling Behavioral Terhadap Perkembangan Moral Siswa SMP Negeri 1 Aramo Tahun Pelajaran 2019/2020"

\section{METODOLOGI PENELITIAN}

Penelitian ini tergolong jenis penelitian eksperimen. Sukaria Sinulingga, (2012:31) mengemukakan bahwa penelitian eksperiman merupakan penelitian yang bertujuan untuk mengetahui atau menyelidiki hubungan sebab akibat serta mengukur berapa besar pengaruhnya sebelum dan setelah mengenakan perlakuan atau treatment pada suatu kelompok eksperimen dan kelompok kontrol. Penelitian ini menggunakan desain Pre-eksperiment yaitu desain the one group pretest-posstest design. Sesuai dengan pengertian penelitian experimen maka dalam penelitian ini metode yang akan digunakan adalah penelitian experimen karena peneliti ingin menguji secara benar hipotesis yang menunjukkan pengaruh variabel penelitian dalam penelitian ini adalah variabel (X) "pelaksanaan konseling behavioral" apakah memberi efek bagi variabel (Y) "perkembangan moral siswa” di SMP Negeri 1 Aramo.

\section{Instrumen Penelitian}

Instrumen penelitian merupakan alat ukur yang digunakan untuk mendapatkan informasi kuantitatif tentang variasi karakteristik secara objektif, sebagai alat pengumpulan data dalam penelitian ini adalah angket tertutup tentang pengaruh konseling behavioral dalam perkembangan moral siswa SMP Negeri 1 Aramo Tahun Pelajaran 2019/2020. Angket merupakan teknik pengumpulan data yang efisien bila peneliti tahu dengan pasti variabel yang akan diukur dan tahu apa yang bisa diharapkan dari responden. model angket yang digunakan adalah model skala Likert, Instrumen ini berisi pernyataan-pernyataan tentang perkembangan moral siswa. Alat pengumpul data utama yang digunakan dalam penelitian ini berupa angket yang dikembangkan sendiri oleh peneliti berdasar dari teori perkembangan moral yang dikembangkan oleh L. Kholberg.

\section{Teknik Pengumpulan Data}

Menurut (Sugiyono, 2012) teknik pengumpulan data merupakan langkah yang paling strategis dalam penelitian, karena tujuan utama dari penelitian adalah mendapatkan data.

Prosedur pengumpulan data merupakan langkah-langkah yang ditempuh penelitian untuk memperoleh data yang diperlukan dalam penelitian dengan menggunakan teknik seperti observasi, wawancara, dokumentasi dan teknik asesmen yang ada dalam Bimbingan dan konseling. Prosedur pengumpulan data dalam penelitian ini adalah sebagai berikut:

1. Mempersiapkan instrumen penelitian secara utuh dan menyeluruh.

2. Menetapkan atau mengecek sumber data, seperti responden, dokumen-dokumen yang diperlukan dan sebagainya.

3. Memberikan penjelasan tentang instrumen dan cara pengisiannya serta mempersilahkan siswa mengisinya.

4. Melakukan pengumpulan data secara sistematis sesuai dengan apa yang telah direncanakan sebelumnya.

5. Melakukan penskoran dan menganalisis data. 


\section{Teknik Analisis Data}

Setelah semua data yang diperlukan diperoleh, langkah berikutnya adalah menganalisa data tersebut, dalam penganalisis data tersebut peneliti menggunakan perbandingan nilai pretest (O1) dengan nilai posttest $(\mathrm{O} 2)$, yang dikemukakan oleh (Harefa, 2018), dengan langkah-langkah sebagai berikut:

1. Setelah semua data diperoleh, data dianalisis dengan mengunakan teknik presentase dari skor mutu dengan menggunakan teknik rumus yang dikemukakan oleh (Sudjana, 2009), yaitu: $P=\frac{\mathrm{f}}{\mathrm{N}} \mathrm{x} 100 \%$

Keterangan:
$\mathrm{P} \quad=$ Angka presentase
$\mathrm{F} \quad=$ Frenkuensi yang sedang dicari presentasenya
$\mathrm{N} \quad=$ Number of cases (jumlah frenkuensi/banyaknya individu)

2. Cari skor dan rata-rata hitungan hasil Pretest (O1) dan Posttest (O2). Untuk mencari rata-rata (mean) mengunakan rumus $\mathrm{M}=\frac{\sum x}{N}$

Keterangan:

$$
\begin{array}{ll}
\mathrm{N} & =\text { Jumlah responden } \\
\mathrm{M} & =\text { Mean }
\end{array}
$$

3. Range, yaitu Range $=$ ST-SR

Keterangan:

$$
\begin{array}{ll}
\text { Range } & =\text { Rentangan dari skor } \\
\text { ST } & =\text { Skor tertinggi } \\
\text { SR } & =\text { Skor terendah }
\end{array}
$$

Hasil tersebut dituangkan dalam bentuk tabel, lalu dibaca dan diuraikan secara dilakukan penafsiran. Dalam penafsiran data, selanjutnya merubah data tersebut dari persentase ke dalam bentuk kriteria-kriteria penafsiran sebagai berikut:

Sedangkan untuk mendeskripsikan perbedaan sebelum diberikan layanan informasi dan sesudah diberikan layanan inforamasi tentang harga diri (self esteem) pada pretest dan posttest digunakan analisis data dengan menggunakan rumus wilcoxon signed rank test yang dapat di uraikan sebagai berikut (Harefa, 2020),

$$
\mathrm{z}=\frac{\mathrm{T}-[1 / 4 \mathrm{~N}(\mathrm{~N}+1)]}{\sqrt{1 / 24(\mathrm{~N})(\mathrm{N}+1)(2 \mathrm{~N}+1)}}
$$

Keterangan:

$\mathrm{T}=$ selisih terkecil

$\mathrm{N} \quad=$ jumlah sampel

Selanjutnya pengambilan keputusan dilakukan dengan membandingkan nilai probabilitas yang diperoleh dengan $\alpha=0,05$ dengan kriteria probabilitas $>0,05$ maka dinyatakan terdapat perbedaan yang signifikan antara pretest dengan Posttest.

\section{HASIL PENELITIAN DAN PEMBAHASAN Hasil}

Hasil penelitian ini diperoleh berdasarkan tujuan penelitian yang telah diuraikan pada bab I yaitu untuk menguji ada tidaknya efektifitas pendekatan konseling behavioral terhadap perkembangan moral siswa SMP Negeri 1 Aramo tahun pelajaran 2019/2020.

\section{a. Deskripsi Data Perkembangan Moral Siswa Sebelum diberikan Pendekatan Konseling Behavioral}

Perkembangan moral siswa sebelum diberikan pendekatan konseling behavioral menunjukkan banyaknya perilaku siswa yang tidak patuh terhadap peraturan yang berlaku di sekolah. Diketahui bahwa banyak siswa yang terlambat datang kesekolah. Selain itu, banyak siswa yang bolos dan tidak masuk kelas bahkan pulang sebelum jam 
pelajaran di sekolah selesai. membuat keributan, berkelahi dan tawuran, serta tidak mengerjakan tugas.

Berdasarkan catatan kasus yang diperoleh dari buku piket harian SMP Negeri 1 Aramo, terdapat 25 siswa yang sering berkasus. Hal ini menunjukkan bahwa siswasiswa tersebut sedang menghadapi masalah dalam diri mereka yang berhubungan dengan perekembangan moral.

Berdasarkan, perhitungan rata-rata perolehan skor dengan total skor secara keseluruhan 1470 dan banyaknya responden berjumlah 25 siswa, Mean $=\frac{\sum f x}{N}=\frac{1412}{25}=56$

Perolehan skor rata-rata hasil prestest 56 artinya bahwa tingkat perkembangan moral siswa sebelum diberikan pendekatan konseling behavioral berada pada kategori sedang. Dengan skor tertinggisebesar 62, skor terendah sebesar 47, dan range sebesar 15. Selanjutnya untuk menghitung frekuensi tingkat perkembangan moral siswa sebelum diterapkan pendekatan konseling behavioral.

Berdasarkan hasil perhitungan persentase perkembangan moral siswa secara keseluruhan sebelum diberikan pendekatan konseling behavioral termasuk kategori rendah, di antaranya 0\% siswa berkategori sangat tinggi, $0 \%$ siswa yang berkategori tinggi, 11 siswa berkategori sedang 44\%, 14 siswa termasuk dalam kategori rendah. Gambaran tingkat perkembangan moral pada grafik 1.1 di bawah ini.

\section{Grafik 1.1Tingkat Perkembangan Moral Siswa}

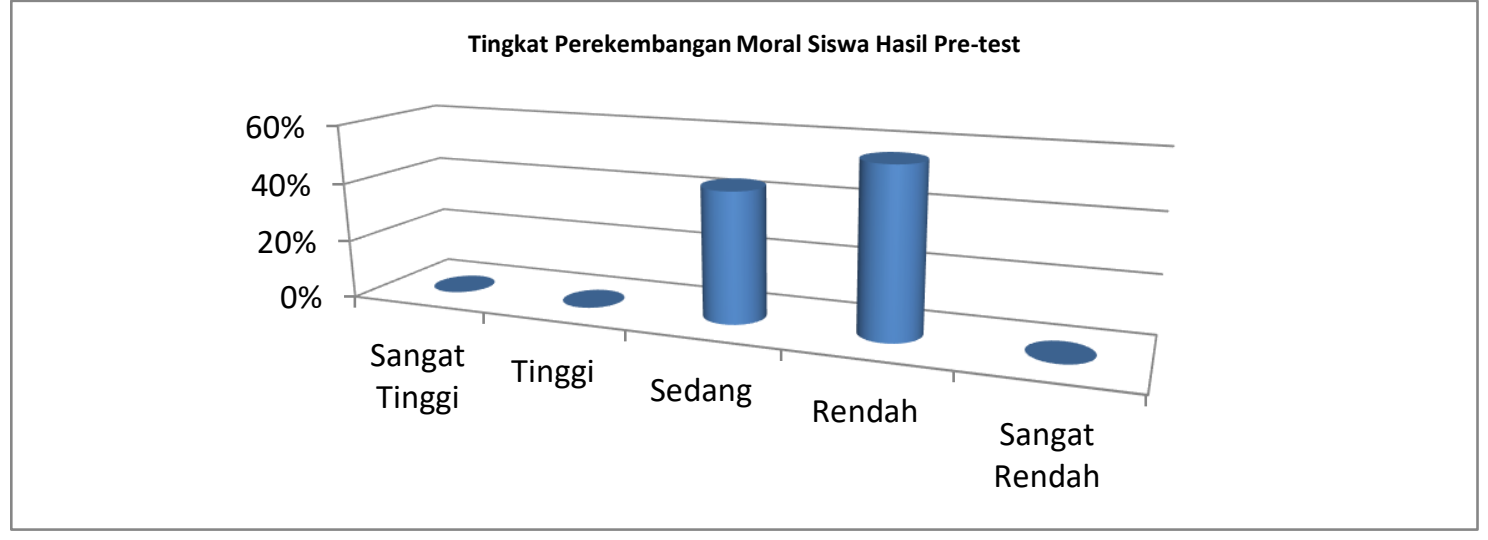

\section{b. Deskripsi Perkembangan Moral Siswa Setelah diberikan Pendekatan Konseling Behavioral}

Tingkat perkembangan moral siswa setelah diberikan layanan pendekatan konseling behavioral, yaitu hasil post-test dapat dilihat berdasarkan data diketahui bahwa perhitungan rata-rata perolehan skor dengan total skor secara keseluruhan 1794 dan banyaknya responden berjumlah 25 siswa diperoleh rata-rata nilai sebagai berikut:

$$
\text { Mean }=\frac{\sum f x}{N}=\frac{1794}{25}=72
$$

Perolehan skor rata-rata hasil post-test 72, artinya bahwa tingkat perkembangan moral siswa setelah diberikan layanan konseling behavioral berada pada kategori tinggi. Dengan skor tertinggi sebesar 79, skor terendah sebesar 62, dan range sebesar 17. Selanjutnya untuk menghitung frekuensi tingkat perkembangan moral siswa setelah diberikan layanan konseling behavioral dapat dilihat berdasarkan hasil perhitungan persentase perkembangan moral siswa secara keseluruhan setelah diberikan pendekatan konseling behavioral mengalami peningkatan yaitu termasuk kategori tinggi, di antaranya $0 \%$ siswa berkategori sangat tinggi, 15 siswa (60\%) yang berkatgori tinggi, 10 siswa berkategori sedang (40\%), 0\% siswa termasuk dalam kategori rendah. Gambaran tingkat perkembangan moral dilihat pada grafik 1.2 di bawah ini. 
Grafik 1.2Tingkat Perkembangan Moral Siswa

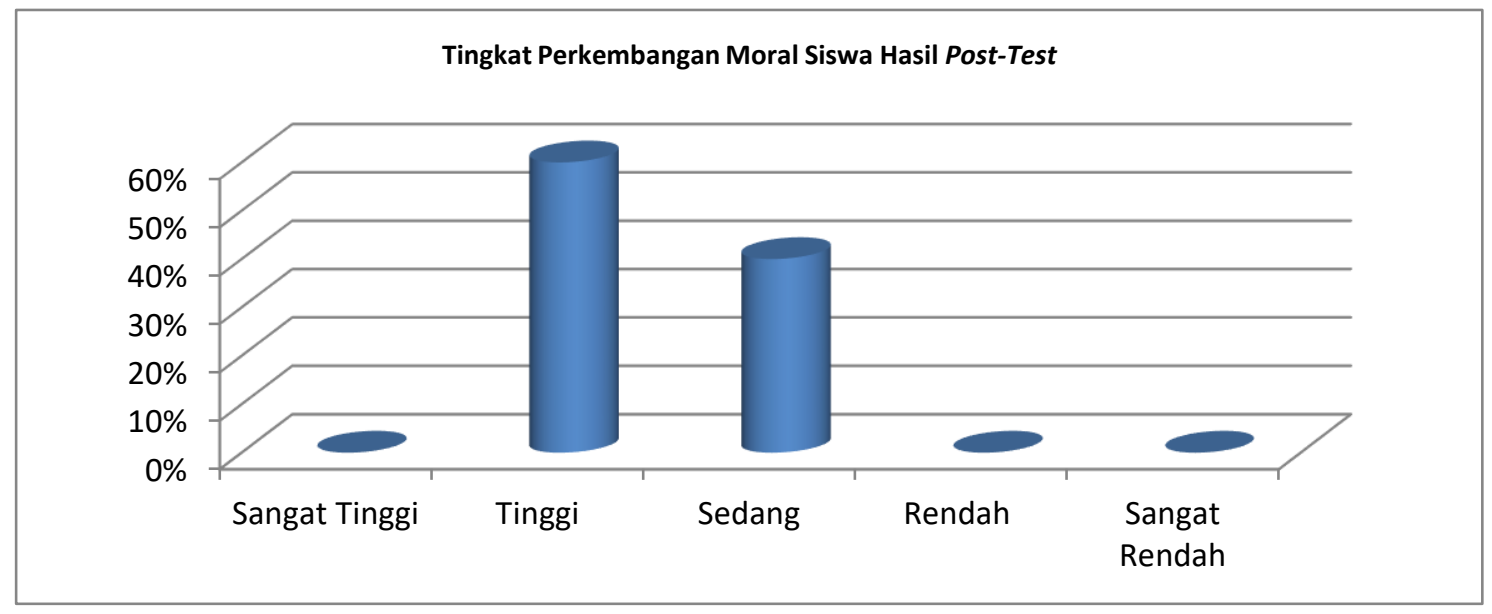

\section{Analisis Data}

\section{a. Efektifitas Pelaksanan pendekatan konseling behavioral Terhadap perkembangan moral siswa}

Untuk mengetahui keefektifan pendekatan konseling behavioral dalam meningkatkan moral siswa dapat dilihat pada perbedaan perolehan skor pada pre-test dan post-test. Hasil perolehan skor pada pre-test dan post-test dapat dilihat berdasarkan hasil rata-rata skor sebelum diberikan layanan pendekatan konseling behavioral sebesar 52 dengan kategori rendah dan rata-rata skor setelah diberikan pendekatan konseling behavioral sebesar 72 dengan kategori tinggi. Berdasarkan persentase tersebut dapat disimpulkan bahwa pendekatan konseling behavioral dapat memberi efek perkembangan moral siswa ke ranah yang positif.

\section{b. Uji F Hitung}

Berdasarkan data penelitian variabel pendekatan konseling behavioral (X) dengan variabel perkembangan moral siswa $(Y)$ maka dapat peroleh besar uji $F_{\text {Hitung }}$ dari kedua variabel tersebut yaitu sebagai berikut.

\section{Tabel 1.2 Hasil Uji F Hitung}

\begin{tabular}{lllllll}
\multicolumn{7}{c}{ ANOVA $^{\mathbf{b}}$} \\
\hline Model & & Sum of Squares & Df & Mean Square & F & Sig. \\
\hline 1 & Regression & 1800.114 & 1 & 1800.114 & $\mathbf{2 9 . 3 0}$ & $\mathbf{. 0 0 0}^{\mathbf{a}}$ \\
& & & & $\mathbf{1}$ & \\
& Residual & 7556.494 & 123 & 61.435 & & \\
& Total & 9356.608 & 124 & & & \\
\hline
\end{tabular}

a. Predictors: (Constant), pendekatan konseling behavioral

b. Dependent Variable: Perkembangan Moral Siswa

Berdasarkan tabel tersebut di atas diperoleh hasil $F_{\text {Hitung }}=29.301>F_{\text {Tabel }}=3,07$ dengan tingkat signifikan $0.000<0,05$ maka model regresi dapat digunakan untuk memprediksi variabel perkembangan moral siswa, dengan kata lain ada hubungan signifikansi pendekatan konseling behavioral (variabel $\mathrm{X}$ ) terhadap perkembangan moral siswa (variabel Y).

\section{c. Uji t}

Pengujian hipotesis dilakukan dengan menggunakan data hasil tes baik variabel bebas (pendekatan konseling behavioral) dan variabel terikat (perkembangan moral siswa). Berdasarkan hasil penelitan, maka diperoleh hasil perhitungan uji hipotesis sebagai berikut. 


\begin{tabular}{|c|c|c|c|c|c|}
\hline \multirow{3}{*}{ Model } & \multicolumn{4}{|c|}{$\begin{array}{l}\text { Tabel 1.3 Hasil Uji t } \\
\text { Coefficients }^{\mathrm{a}}\end{array}$} & \multirow{4}{*}{$\begin{array}{l}\text { Sig. } \\
.000\end{array}$} \\
\hline & \multicolumn{2}{|c|}{$\begin{array}{l}\text { Unstandardized } \\
\text { Coefficients }\end{array}$} & \multirow{3}{*}{$\begin{array}{l}\text { Standardized } \\
\text { Coefficients } \\
\text { Beta }\end{array}$} & \multirow{3}{*}{$\begin{array}{c}\mathrm{T} \\
7.523\end{array}$} & \\
\hline & $\mathrm{B}$ & Std. Error & & & \\
\hline $1 \quad$ (Constant) & 51.840 & 6.890 & & & \\
\hline $\begin{array}{l}\text { pendekatan } \\
\text { konseling } \\
\text { behavioral }\end{array}$ & .268 & .050 & .439 & 5.413 & .000 \\
\hline
\end{tabular}

a. Dependent Variable: Perkembangan moral Siswa

Berdasarkan tabel 4.7 tersebut di atas diperoleh hasil $t_{\text {hitung }}$ sebesar 5,413 dan kemudian dikonsultasikan pada daftar $t_{\text {tabel }}$ dengan taraf signifikan 0,05 dan $d k=n-$ $2=125-2=123$. Maka $t_{\text {tabel }}=1.979$, sehingga diperoleh $t_{\text {hitung }}=5,413>$ $t_{\text {tabel }}=1,979$ yang artinya: $H_{0}$ ditolak dan $H_{a}$ diterima, sehingga hipotesis penelitian yang berbunyi: "terdapat Efektifitas signifikan antara pendekatan konseling behavioral terhadap perkembangan moral siswa SMP Negeri 1 Aramo Tahun Pelajaran 2019/2020 diterima pada taraf signifikan 0,05 .

Kemudian, diperoleh nilai konstanta $(\alpha)$ sebesar 51,840 yang artinya jika ada pendekatan konseling behavioral (variabel X) maka tingkat nilai perkembangan moral siswa (variabel Y) adalah sebesar 51,840. Selanjutnya, nilai angka koefisien regresi (b) sebesar 0,268 yang artinya setiap penambahan $1 \%$ pendekatan konseling behavioral (variabel X) maka perkembangan moral siswa (variabel Y) akan meningkat sebesar 0,268 . Oleh karena nilai koefisien regresi bernilai positif $(0,268)$ maka pendekatan konseling behavioral (variabel $\mathrm{X}$ ) berpengarh positif terhadap perkembangan moral siswa (variabel Y). Sehingga persamaan regresi dalam penelitian ini adalah $\mathrm{Y}=51,840$ $+0,268 X$.

\section{Pembahasan}

Berdasarkan hasil penelitian di SMP Negeri 1 Aramo Tahun Pelajaran 2019/2020 menunjukkan perkembangan moral siswa ke arah yang positif di mana hasil post-test setelah diberikan layanan pendekatan konseling behavioral mengalami peningkatan dari kategori rendah ke kategori tinggi dengan rata-rata skor pada saat pre-test 56 menjadi 72 pada hasil post-test.

Hasil angket tersebut dapat menegaskan bahwa pendekatan konseling behavioral dapat diterapkan untuk memecahkan masalah moral siswa yang kerap sekali melanggar peraturan sekolah. Tindakan melanggar peraturan sekolah merupakan bagian dari masalah perkembangan moral yang dihadapi oleh siswa. Permasalah tersebut bersifat penting untuk diatasi karena dapat mengakibatkan kerugian pada diri siswa sendiri dan juga teman-teman mereka. Siswa yang sering melakukan tindakan yang menyimpang akan sulit diterima oleh teman sejawat atau kelompok sosial. Oleh karena itu, konselor perlu melakukan pendekatan untuk mengarahkan perkembangan moral siswa ke hal-hal yang positif. Sebagaimana (Hurlock, 1980) mengemukakan bila salah satu tugas perkembangan penting yang harus dikuasai remaja adalah mempelajari apa yang diharapkan kelompok dari padanya dan kemudian mau membentuk perilakunya agar sesuai dengan harapan sosial tanpa terus dibimbing, didorong, dan diancam hukuman seperti yang dialami sewaktu anak-anak.

Perkembangan moral adalah hal yang lazim dialami oleh setiap individu. Namun, besar kemungkinan terjadinya tindakan-tindakan yang menyimpang dalam fase ini. Menurut (Jumanta, 2014) Perkembangan moral adalah perkembangan yang berkaitan 
dengan aturan dan konvensi mengenai apa yang seharusnya dilakukan oleh manusia dalam interaksinya dengan orang lain. Perkembangan moral adalah perubahanperubahan perilaku yang terjadi dalam kehidupan anak berkenaan dengan tatacara, kebiasaan, adat, atau standar nilai yang berlaku dalam kelompok sosial".

Jadi dalam lingkungan sekolah siswa diharap dapat mengikuti aturan sekolah dan belajar dari sekolah tentang perilaku agar dapat dikatakan memiliki perkembangan moral yang baik.

Salah satu upaya yang dapat dilakukan konselor untuk mengatasi masalah yang dihadapi klien pada perkembangan moral ini adalah dengan memberikan pendekatan konseling behavioral. Menurut (Willis, Sofyan, n.d.) konseling behavioral adalah "suatu proses membantu orang untuk belajar memecahkan masalah interpersonal, emosional, dan pengambilan keputusan. Penekanan istilah belajar dalam pengertian ini adalah dengan menciptakan kondisi yang sedemikian rupa sehingga klien dapat memecahkan masalahnya. Dalam konsep behavioral, perilaku merupakan hasil belajar, sehinga dapat diubah dengan manipulasi dan mengkreasi kondisi-kondisi belajar. Pada dasarnya, proses konseling merupakan suatu penataan proses atau pengalaman belajar untuk membantu individu mengubah perilakunya agar dapat memecahkan masalah.

Berdasarkan hasi skor variabel pendekatan konseling behavioral (X) dengan variabel perkembangan moral siswa (Y) diperoleh sebesar 0,439 dan berada pada nilai 0,40-0,599 dengan kategori sedang. Hasil perhitungan uji determinasi $=0,192=19,2 \%$ yang artinya pengaruh pendekatan konseling behavioral terhadap perkembangan kepribadian siswa sebesar 19,2\%. Sedangkan 80,8\% dipengaruhi oleh variabel lain yaitu faktor dari dalam siswa adalah kepribadian yang diperoleh sejak lahir yang merupakan warisan dari keluarga siswa tersebut dan faktor dari luar adalah kepribadian terbentuk karena lingkungan siswa itu berada yang diperoleh dari teman-teman sebayanya, guruguru di sekolah, faktor perkembangan siswa itu sendiri, faktor kemampuan siswa itu sendiri dalam merespon suatu stimulus dan lain sebagainya.

Hasil perhitungan uji hipotesis diperoleh hasil $t_{\text {hitung }}=5,413>t_{\text {tabel }}=1,979$ yang artinya: $H_{0}$ ditolak dan $H_{a}$ diterima, dengan kata lain terdapat efektifitas antara Pendekatan konseling behavioral terhadap perkembangan moral siswa SMP Negeri 1 Aramo tahun pelajaran 2019/2020 dengan persamaan regresinya yaituY $=51,840+$ 0,268X, dapat diartikan bahwa, bila pendekatan konseling behavioral bertambah 1 , maka tingkat perkembangan moral siswa akan bertambah 0,268 dengan kata lain pendekatan konseling behavioral telah mampu mengarahkan perkembangan moral siswa ke dalam tindakan-tindakan yang positif.

Berdasarkan pembahasan di atas menunjukkan bahwa pendekatan konseling behavioral memiliki efektifitas yang signifikan terhadap perkembangan moral siswa dengan kata lain pendekatan konseling behavioral dapat mengubah kebiasaan siswa yang menyimpang.

\section{PENUTUP}

Terdapat efektifitas signifikan antara pendekatan konseling behavioral terhadap perkembangan moral siswa SMP Negeri 1 AramoTahun Pembelajaran 2019/2020 ratarata skor pada pre-test 56 menjadi 72 pada hasil post-test. Perolehan rata skor pada pretest berada pada kategori rendah, sedangkan pada perolehan skor post-test mencapai kategori tinggi.

Berdasarkan hasil penelitin dan pembahasan, maka dapat disimpulkan bahwa:

1. Tingkat Perkembangan Moral Siswa SMP Negeri 1 Aramo Tahun Pelajaran 2019/2020 sebelum diberikan Pendekatan Konseling Behavioral berada pada kategori rendah dengan nilai rata-rata skor 56, hal ini menunjukkan bila tingkat 
perkembangan moral siswa sebelum diberikan perilaku masih berada pada tingkat yang perkembangan moral yang rendah.

2. Tingkat Perkembangan Moral Siswa SMP Negeri 1 Aramo Tahun Pelajaran 2019/2020 setelah diberikan Pendekatan Konseling Behavioral berada pada kategori tinggi dengan nilai rata-rata skor 72, artinya pendekatan konseling behavioral efektif terhadap perkembangan moral siswa, karena setelah diberi perlakuan skor nilai menunjukkan peningkatan nilai perkembangan moral yang tinggi.

3. Berdasarkan hasil uji hipotesis menunjukkkan pendekatan konseling behavioral terhadap Perkembangan Moral Siswa SMP Negeri 1 Aramo. Dimana diperoleh $T_{\text {hitung }}$ sebesar $465>T_{\text {tabel }}$ sebesar 1.979 ,. Maka $H_{a}$ diterima dan $H_{0}$ di tolak, dari hasil ini dapat disimpulkan bila pelaksanaan pendekatan konseling behavioral sangat membantu siswa dalam perkembangan moral.

\section{DAFTAR PUSTAKA}

Harefa, D., Sarumaha, M. (2020). Teori Pengenalan Ilmu Pengetahuan Alam Sejak Dini. PM Publisher.

Harefa, D. (2017). Pengaruh Presepsi Siswa Mengenai Kompetensi Pedagogik Guru Dan Minatbelajar Siswa Terhadap Prestasi Belajar Ilmu Pengetahuan Alam (Survey pada SMK Swasta di Wilayah Jakarta Utara). Horison Jurnal Ilmu Pendidikan Dan Lingusitik, 7(2), 49-73.

Harefa, D. (2018). Efektifitas Metode Fisika Gasing Terhadap Hasil Belajar Fisika Ditinjau Dari Atensi Siswa (Eksperimen Pada Siswa Kelas Vii Smp Gita Kirtti 2 Jakarta). Faktor Jurnal Ilmiah Kependidikan, 5(1), 35-48.

Harefa, D. (2020). Differences In Improving Student Physical Learning Outcomes Using Think Talk Write Learning Model With Time Token Learning Model. Jurnal Inovasi Pendidikan Dan Sains, 1(2), 35-40.

Hurlock, E. B. (1980). Perkembangan Anak. (edisi Keenam). Terjemahan oleh Med. Meitasari Tjandrasa. Penerbit Erlangga.

Jumanta, H. (2014). Model dan Metode Pembelajaran kreatif dan berkarakter. Penerbit Ghalia indonesia.

Laia, B. (2018). KONTRIBUSI MOTIVASI DAN MINAT BELAJAR TERHADAP KEMAMPUAN BERBICARA BAHASA INGGRIS MAHASISWA PROGRAM STUDI BIMBINGAN KONSELING STKIP NIAS SELATAN. Jurnal Education and Development, 6(1), 70-77.

Laia, B. (2019a). Improving the Students' Ability in Speaking by Using Debate Technique at the Tenth Grade of SMK Negeri 1 Aramo. Scope: Journal of English Language Teaching, 4(1), 1-9.

Laia, B. (2019b). SOCIAL INJUSTICE IN STELLA KNIGHTLEY'S NOVEL GIRL BEHIND THE MASK. Jurnal Education and Development, 7(4), 315-326.

Sarumaha, M., L. (2018). Increasing the Activities and Competencies of Learning Science through Problem Based Learning. International Journal of Progressive Sciences and Tecnology, 10(1), 49-49.

Sudjana. (2009). Metode Statiska. Tarsito.

Sugiyono. (2012). Metode Penelitian Kuantitatif Kualitatif dan R\&D. Bandung. Alfabeta.

Willis, Sofyan, S. (n.d.). Konseling Indvidual: Teori dan Praktik. Alfabeta. 